\title{
ASSUMING REGULATORY AUTHORITY FOR TRANSNATIONAL TORTS: AN INTERSTATE AFFAIR? A HISTORICAL PERSPECTIVE ON THE CANADIAN PRIVATE INTERNATIONAL LAW TORT RULES
}

\section{Roxana Banu*}

In Tolofson v. Jensen, the Supreme Court of Canada determined that in most cases the law of the place where the tort occurred has exclusive authority to regulate all legal aspects related to it. In developing this choice of law rule, the Supreme Court relied on an analogy between Private International Law and Public International law. This allows Private International Law to claim a structural, neutral function in the distribution of legislative authority in the international realm and to ignore both private law and public law considerations. To best reveal the way in which the Supreme Court injected these limitations into Private International Law by reference to Public International Law, I show the striking similarity between the Supreme Court's reasoning and several Private International Law writings at the end of the $19^{\text {th }}$ century in Continental Europe.

In the context of the extraterritorial tortious activity of multinational corporations, these limitations make Private International Law oblivious to arguments of Corporate Social Responsibility scholars showing that a multinational corporation may legitimately be regulated by the state of its headquarters, even for extraterritorial conduct. Overall, I argue that an overemphasis on legislative authority as a symbol of state sovereignty transforms Private International Law matters generally, and transnational torts in particular, in inter-state affairs, removed from the interests and pleas of the individuals and communities affected by them.

Dans l'arrêt Tolofson c. Jensen, la Cour suprême du Canada a décidé que, dans la plupart des cas, la loi du lieu où le délit a été commis régit exclusivement tous les aspects juridiques qui s'y rapportent. Pour établir cette règle du choix de la loi applicable, la Cour suprême s'est fondée sur une analogie entre le droit international privé et le droit international public. Cela permet au droit international privé de réclamer une fonction structurelle et neutre au niveau de la distribution du pouvoir législatif dans le domaine international et d'ignorer tant les considérations de droit privé que les considérations de droit public. Pour mieux illustrer la façon dont la Cour suprême a inséré de telles restrictions dans le droit international privé par renvoi au droit international public, je démontre la similitude frappante entre le raisonnement de la Cour suprême et de nombreux écrits en droit international privé à la fin du $19^{e}$ siècle en Europe continentale.

SJD Candidate, University of Toronto, Faculty of Law; Visiting Doctoral Researcher, New York University School of Law. I am greatly indebted to Professors Karen Knop, Catherine Valcke and Robert Wai for their outstanding supervision and guidance of my doctoral research which this paper is connected to. I am also very grateful to Joanna Langille, Andrei Banu, Marilena \& Ion Popescu, the participants of the Windsor Conference on Justice Beyond the State, as well as two anonymous reviewers, for their generosity in offering comments and suggestions for this paper. 
Dans le contexte des activités délictueuses extraterritoriales des sociétés multinationales, de telles restrictions rendent le droit international privé insensible aux arguments des universitaires prônant la responsabilité sociale des entreprises selon lesquels une société multinationale peut légitimement être régie par l'État où est situé son siège social, même pour sa conduite extraterritoriale. Dans l'ensemble, je fais valoir qu'une trop grande importance accordée au pouvoir législatif comme symbole de la souveraineté étatique transforme les affaires relevant du droit international privé en général et les délits transnationaux en particulier en affaires interétatiques qui ne tiennent pas compte des intérêts et demandes des particuliers et collectivités qu'elles touchent.

\section{INTRODUCTION}

Transnational torts ${ }^{1}$ pose a serious regulatory problem. For example, when a company like Chevron conducts mining operations in Ecuador which cause water pollution, deforestation, soil contamination, and spreading of various diseases amongst the local population, a fundamental question arises as to what standard of care the corporation should be held to: the law of its headquarters (home state law) or the law of the place where the mining operation was conducted (host state law). ${ }^{2}$ This is an especially important question when the tort laws of the state where the tort occurred (lex loci delicti) provide for a lower standard of care and/or lower compensation quantum than the home state laws.

On the one hand, the application of the corporation's home state law would eliminate an international regulatory gap and the corresponding incentives for corporations to operate in countries with less strict regulatory standards. ${ }^{3}$ On the other hand, one might wonder whether it is fair to hold them to the standard of their home state law, despite the fact that their operations were conducted abroad.

Two main options are available in the legal realm to respond to the question of the applicable law for torts which occur outside the tortfeasor's home state. One option is to pass laws which regulate specifically this type of extraterritorial conduct. Another option is to determine when the tortfeasor's home state law will apply outside its borders. The latter represents one of the main issues for the field of Private International Law (also known as Conflict of Laws). In Private International Law [PRIL], this issue is known as the choice of law question.

To increase corporate social responsibility, scholars look to Public International Law, International Business and Trade Law and International Human Rights Law to establish an obligation on the home

1 Rules of choice of law apply to claims in tort where any of the material facts connect to a jurisdiction other than that of the deciding forum. This paper focuses on torts committed outside of the defendant's home state.

2 For an overview of the factual circumstances and judicial history of the case see e.g. Lucien J Dhooge, “Aguinda v. Texaco: Mandatory Grounds for the Non-Recognition of Foreign Judgments for Environmental Injury in the United States” (2010) 17 Fla St J Transnat'l L \& Pol'y 1.

3 Joel R Paul, “The Isolation of Private International Law” (1988) 7 Wis Int'l LJ 149; Robert Wai, “In the Name of the International: The Supreme Court of Canada and the Internationalist Transformation of Canadian Private International Law” (2001) 39 Can YB Int’l L 117; Horatia Muir Watt, “Private International Law Beyond the Schism” (2011), 2 Transnational Legal Theory 347; Robert McCorquodale \& Penelope C Simons, "Responsibility Beyond Borders: State Responsibility for Extraterritorial Violations by Corporations of International Human Rights Law” (2007) 70 Mod L Rev 598. 
state to regulate the conduct of corporations operating abroad. ${ }^{4}$ Similarly, several interesting perspectives are offered to show why a corporation's home state law may still legitimately apply to regulate the tortfeasor's (defendant) conduct abroad. ${ }^{5}$ However, this presupposes that the question is indeed about legitimacy relative to the defendant. Yet in PRIL, the legal field where these theoretical perspectives would find their most fruitful practical application, the question is only marginally asked in this way. Rather, PRIL often aims to achieve universal consensus on the proper division of regulatory authority among states. In this way, the question of the legitimacy of the exercise of the home state's authority is asked not in relationship to the defendant, but rather in relationship to the state where the conduct occurred.

In the first part of this paper I show that the Supreme Court of Canada adopted this state-centred approach to transnational torts in the leading case of Tolofson $v$ Jensen. ${ }^{6}$ There, the Supreme Court decided that the law of the place of the tort determines any rights and liabilities resulting from the tort. While the Court did not admit any exception in the inter-provincial context, it acknowledged that an exception might be needed in the international context when the application of the law of the place of the tort would cause an "injustice". 7 However, because of the Court's insistence that this exception should operate in exceptional circumstances, as well as the lack of guidance as to what those circumstances might be, the case-law following Tolofson shows that "the current trend is to limit the situations in which the lex loci delicti can be displaced". 8

Tolofson generated considerable criticism in the PRIL literature. ${ }^{9}$ On the one hand, Wai argued that Tolofson was motivated by the Supreme Court's naïve internationalist outlook on PRIL. ${ }^{10}$ On the other hand, Hume argued that the Supreme Court's PRIL jurisprudence, including Tolofson, is in fact characterized by conceptual incoherence. ${ }^{11}$ This made it difficult to explain what motivated and connected the Supreme Court's main arguments in Tolofson including its excessive focus on predictability, ${ }^{12}$ the downplaying of considerations of fairness and parties' reasonable expectations, ${ }^{13}$ as well as the various analogies with Public International Law [PIL] and foreign law sources. ${ }^{14}$

$4 \quad$ See e.g. Penelope Simons, "International Law’s Invisible Hand and the Future of Corporate Accountability for Violations of Human Rights” (2012) 3 Journal of Human Rights \& the Environment 5.

5 See e.g. Sara Seck, "Home State Responsibility and Local Communities: The Case of Global Mining” (2008) 11 Yale Human Rts \& Dev LJ 177; Sara Seck, "Transnational Business and Environmental Harm: A TWAIL Analysis of Home State Obligations” (2011) 3 Trade, Law \& Development 164; Penelope Simons \& Audrey Macklin, Extractive Industries, Human Rights, and the Home State Advantage (New York: Routledge, 2014).

6 Tolofson $v$ Jensen [1994] 3 SCR 1022 [Tolofson].

$7 \quad$ Ibid at para 50.

$8 \quad$ SGA Pitel \& Jesse Harper, “Choice of Law for Tort in Canada: Reasons for Change” (2013) 9 J P Int'l L 289; Wong v Lee [2002] 58 OR (3d) 398; Somers v Fournier [2002] 60 OR (3d) 225.

$9 \quad$ For an early analysis, see JG Castel, "Back to The Future! Is the 'New’ Rigid Choice of Law Rule for Interprovincial Torts Constitutionally Mandated?” (1995) 33 Osgoode Hall LJ 35.

10 Wai, supra note 3.

11 Nathan Hume, "Four Flaws: Reflections on the Canadian Approach to Private International Law” (2006) 44 Can YB Int'l Law 161.

12 Pitel \& Harper, supra note 8 at 299.

13 J Walker, “'Are We There Yet?’ Towards a New Rule for Choice of Law in Tort” (2000) 38 Osgoode Hall LJ 331 at 345-46; Peter Kincaid, "Jensen v. Tolofson and the Revolution in Tort Choice of Law” (1995) 74 Can Bar Rev 537; Peter Kincaid, “Justice in Tort Choice of Law” (1996) 18 Adel LR 191.

14 Wai, supra note 3; Hume, supra note 11. 
I argue that all these policies are generated by the Supreme Court's adoption of a particular kind of universalist outlook in PRIL which is overly state-centric. I will show that there are four elements which are incorporated within what I label a "state-centric universalist” conceptualization of choice of law:

attempting to deduce choice of law rules from general principles of PIL, conceptualizing PRIL matters as "structural problems", linking PRIL policies to those of PIL, and a resistance to relying on parties' reasonable expectations as a guiding policy in the choice of law analysis.

Each of these aspects appears to both generate and rely on the other under the state-centric understanding of PRIL matters as conflicts of sovereign authority. This creates a self-perpetuating line of reasoning which explains the extraterritorial application of law in tort matters only in terms of state sovereignty and comity.

I believe this state-centered bias in PRIL theory is best revealed when the Court's reasoning in Tolofson is compared to what became known as "the law of nations doctrine" in continental Europe in the second half of the $19^{\text {th }}$ century and the first few decades of the $20^{\text {th }}$ century. ${ }^{15}$ I rely on this analogy in the second part of the paper to underscore the impact made by choosing the state over the individual or community as the addressees of choice of law rules and policies, especially in the area of tort law. This would hopefully open up doctrinal and jurisprudential conversations about choice of law rules in tort matters to include arguments regarding the validity of the application of the defendant's law of domicile for certain torts.

By underscoring the a priori choice of an unprincipled state-centric universalist conceptualization of choice of law, the Supreme Court's conceptual pillars collapse and the extraterritorial application of law in tort matters can be asked anew from a different angle, focused on the needs of the litigating parties and the local community affected by the tort.

\section{THE LIMITATIONS OF PRIL IN REGULATING TRANSNATIONAL TORTS}

In 1994 the Supreme Court of Canada decided two joined cases (Tolofson ${ }^{16}$ ) involving parties injured in two separate automobile accidents. The parties did not reside in the provinces where the accidents occurred and the plaintiffs sued in their respective provinces of residence. In the first case, the law of Saskatchewan, the place of the accident, provided for a shorter statute of limitations and a lower standard of care for torts against a gratuitous passenger than the law of British Columbia which was the place of residence of both parties. In the second case, the law of Quebec, the place of the accident, provided for a lower damage quantum than the law of Ontario which was the place of residence of both

\footnotetext{
15 Arthur Nussbaum, "Rise and Decline of the Law-of-Nations Doctrine in the Conflict of Laws" (1942) 42 Colum L Rev 189.

16 Tolofson, supra note 6.
} 
parties. ${ }^{17}$ In both cases, lower courts decided that the law of the forum applied, while the Supreme Court determined that the law of the place of the tort should apply.

The Supreme Court of Canada used the opportunity to offer what it viewed as the general theoretical and practical context of choice of law rules in tort matters, as well as to outline some fundamental pillars of its philosophy of choice of law in general. This section argues that four of those pillars inject serious limitations of choice of law rules in regulating transnational torts. Furthermore, it reveals the circularity of the argument regarding the scope of tort choice of law rules, based on the association between Public and Private International Law.

\section{A. From General Principles of Public International Law to Choice of Law Rules}

The Supreme Court's reform ${ }^{18}$ of Canadian tort choice of law rules in Tolofson ${ }^{19}$ was set in motion by what it perceived to be a fundamental disconnect between Anglo-Canadian choice of law rules "as developed over the past century" and "the underlying reality in which they operate and the general principles that should apply in responding to that reality" ${ }^{20}$ According to the Supreme Court the reality which "must be reflected and accommodated in private international law" is derived from "the underlying postulate of public international law that generally each state has jurisdiction to make and apply law within its territorial limit". ${ }^{21}$ The Court believed it imperative to create a "rational and workable system of private international law" in line with "the underlying reality of the international legal order" ${ }^{22}$ In the Court's view, this obliges states to respect the absolute right of a state to regulate conduct occurring in its territory. ${ }^{23}$

This implied inter-state code of conduct makes the principle of territoriality appear "axiomatic" which in turn leads the Court to conclude that states should be "hesitant to interfere with what another state chooses to do within those limits". ${ }^{24}$ "This, it was thought, was in conformity with the requirements of comity, the informing principle of private international law which has been stated to be the deference and respect due by other states to the actions of a state legitimately taken within its territory”. ${ }^{25}$ The choice of law rules in PRIL must therefore correspond to PIL principles of division of authority among states, regardless of whether or not these principles, including that of territoriality, were

17 The defendant initially cross-claimed against a Quebec resident and the question arose whether the cross claim would change the analysis of the applicable law. However, the cross-claim became irrelevant in light of the Supreme Court's decision to apply the law of the place of tort for all torts. The tort choice of law rules prior to Tolofson required the plaintiff to show that the defendant's conduct was actionable under both the law of the place of the tort and the law of the forum. See McLean $v$ Pettigrew [1945] SCR 62.

19 Tolofson v. Jensen is part of a series of cases, which contributed to the adoption of an internationalist outlook on PRIL and the discussion of PRIL in the context of constitutional imperatives. For an analysis on how Tolofson relates to other cases which contributed to the reform of Canadian PRIL see Wai, supra note 3; Hume, supra note 11.

Tolofson, supra note 6 at para 36.

Ibid at para 37.

Ibid.

Ibid. For an overview of how the significance of the concept of comity changed over time see Paul, supra note 3.

Tolofson, supra note 6 at para 37.

Ibid at para 39. 
ever designed to cover PRIL matters. ${ }^{26}$ Rather, the court seemed to take for granted that states share "the same expectation" that a tort would be regulated by the law of the place where it occurred. ${ }^{27}$

This initial setting of PRIL matters within the context of PIL disconnects PRIL from private law, here, tort law. The a priori choice of territoriality as the governing principle and the assumption that this corresponds to states' reasonable expectations and to a universal obligation to respect it, precludes courts from an analysis of the nature of torts and tort laws. In contrast, several $19^{\text {th }}$ century authors who linked PRIL to private law, rather than PIL, reflected on the nature of tort laws. For example, the German scholar Friedrich Carl von Savigny (1779-1861) argued that a thorough analysis of private law reveals that tort laws could be seen as "anomalous", "quasi-penal”, "coercitive” and restrict substantially the autonomy of the parties which he viewed as essential to private law and implicitly also PRIL. ${ }^{28}$ Because of this clash between private autonomy and the myriad of public considerations that tort law needs to address, he argued that the court deciding the matter (i.e. the forum) should apply its own law. ${ }^{29}$ Other $19^{\text {th }}$ century scholars have argued that there is an inherent correlation between the obligation for compensation and the commission of a tort, so that no law that denies liability should be applied, no matter which state enacted it. ${ }^{30}$ Regardless of the validity of any of these considerations, the relatively sterile relationship between Public and Private International Law exemplified in Tolofson excludes them from the analysis of the applicable law in tort matters.

Furthermore, even if one abandons this valuable association between PRIL and private law and assumes that PRIL must solely cater to an expectation that the law of the state where the tort occurred applies, this assumption can lead to quite absurd results when the state of the tort would prefer or expect the application of the law of the defendant's domicile. In other words, not only is state sovereignty a questionable justification for the settlement of conflict of laws, but the alleged deterrence of paternalism which is claimed to justify the application of the law of the place of the tort can be used as a façade hiding the unwillingness of a state to impose a high damage quantum and liability for the conduct of its corporations abroad. ${ }^{31}$

This situation is exemplified by the Union Carbide ${ }^{32}$ case in which India sought to have the case tried in the US, primarily because of the higher standard of care and quantum damage of US tort law. ${ }^{33}$ In this circumstance if the imposition of the law of the place of tort was meant to cater to that state's expectation, India seemed to have waived such right to have its law applied. Instead, the US court reasoned that "to deprive the Indian judiciary of this opportunity to stand tall before the world and to

26 For a general overview regarding the use of the principle of territoriality in PIL see Gerhard Kegel \& Ignaz SeidlHohenveldern, “On the Territoriality Principle in International Law” translated by Joseph J Darby (1981) 5 Hastings Int'l \& Comp L Rev 245.

27 Tolofson, supra note 6 at para 44.

28 FC von Savigny, Private International Law and the Retrospective Operation of Statutes: A Treatise on the Conflict of Laws and the Limits of their Operation in Respect of Place and Time, translated by William Guthrie (Edinburgh: T \& T Clark, 1880) at 76, 233, 253.

29 Ibid. According to his theory, since the courts in the state of the defendant's domicile usually have jurisdiction to hear tort matters, they would apply the law of the forum.

30 Josephus Jitta, La substance des obligations dans le Droit International Privé, vol 2 (Hague: Belifante Frères, 1907) at 323, 334.

31 See Paul, supra note 3 at 171.

32 In re Union Carbide, 634 F. Supp. at 867.

33 The case dealt with the question of the applicable law only as an aspect to be considered in the analysis of jurisdiction. 
pass judgment on behalf of its own people would be to revive a history of subservience and subjugation from which India has emerged. India and its people can and must vindicate their claims before the independent and legitimate judiciary created there since the Independence of 1947”. ${ }^{34}$

Under the veil of an alleged "intrusion" into the affairs of another state, ${ }^{35}$ the proposition that the application of law extraterritorially could be justified by the fact that the forum might offer the state of the tort a helping hand by applying its own law and increasing the applicable standard of care becomes more of an illusion. ${ }^{36}$

\section{B. PRIL Matters are Structural Problems}

Associating PRIL with PIL may look quite progressive at first sight. Indeed, in Tolofson the Court viewed this as an adaptation of PRIL to modern realities and a long awaited response to the needs of international society. ${ }^{37}$ However, the court constructed quite a specific relationship between PRIL and PIL, the nuances of which become most clear when the court refers to PRIL matters as "structural problems". ${ }^{38}$ Allegedly, "in dealing with legal issues having an impact in more than one legal jurisdiction, we are not really engaged in that kind of interest balancing”. ${ }^{39}$ Engaging in a balancing of private and public interests and questioning how those might relate to each other rather "wholly obscures the nature of the problem”. 40

Therefore, for the Court, PRIL is simply concerned with a universal a priori division of legislative authority between states. The content of the laws are irrelevant. Choice of law rules are seen as "secondary" norms which merely choose a "primary" law from those possibly applicable. ${ }^{41}$ In this way, they are not concerned with the implications of the application of one or the other law. ${ }^{42}$

Because of this additional limitation placed on PRIL, the PIL - PRIL association envisioned here is far from the "creative fusion of public and private international law" which "eschewed formalism" and was based on an enlightened idea of the international "public good" that Joel R. Paul captured in the

34 Paul, supra note 3. For a thorough analysis of the case and its implications see Upendra Baxi, Inconvenient Forum and Convenient Catastrophe: the Bhopal Case (Bombay: TM Tripathi, 1986); Upendra Baxi \& Thomas Paul, Mass Disasters and Multinational Liability: The Bhopal Case (Bombay: TM Tripathi, 1986).

35 Tolofson, supra note 6 at para 28.

36 For the proposition that the imperialistic connotation of the application of the home state's law could be trumped by the democratic inclusion of host state local communities see Sara Seck, "Unilateral Home State Regulation: Imperialism or Tool for Subaltern Resistance?” (2008) 46:3 Osgoode Hall LJ 565.

37 Tolofson, supra note 6 at paras 36, 37.

$38 \quad$ Ibid at para 36.

39 Ibid.

40 Ibid.

41 Alex Mills, The Confluence of Public and Private International Law, Justice, Pluralism and Subsidiarity in the International Constitutional Ordering of Private Law (Cambridge UK: Cambridge University Press, 2009).

42 It should be noted that even when the determination of the applicable law is made independently of the content of the substantive norms, the result of the application of the norms can still be tested on normative, rather than territorial criteria. For example, Paul Schiff Berman suggests that the question of the applicable law must remain independent of the content of the norms and be based on an assessment of the relationship between the parties and the various jurisdictions, but at the same time he adds that the result should be tested against the goal that choice of law rules should not lead to "a race to the bottom” of legal norms. Paul Schiff Berman, Global Legal Pluralism, A Jurisprudence of Law Beyond Borders (Cambridge UK: Cambridge University Press, 2012). 
jurisprudence of the $19^{\text {th }}$ century American judge Joseph Story (1779-1845). ${ }^{43}$ The kind of relationship that the Supreme Court of Canada envisioned is clearly not one that would account for the systemic implications of tortious conduct of corporations on the labor market, social and economic development, or the environment, nor one that would facilitate a thorough analysis of why and when any of these public concerns should trump private interests and expectations. The Supreme Court in fact believed this kind of analysis "obscures" the "structural" nature of the problem.

Within the ambit of this particular association between PRIL and PIL, PIL is not acting as a set of international substantive public norms which could be included in the analysis of the applicable law in cross-border torts. Rather, PRIL norms are viewed as a quasi-constitutional set of norms which delimit authority among states in broad terms and in broad categories of cases. In this way, PRIL is disconnected from public law considerations as well, despite its association with PIL, or rather because of the way in which the PIL-PRIL association is constructed. After all, according to the Court, "public policy arguments simply mean that the court does not approve of the law that the legislature having power to enact it within its territory has chosen to adopt" ${ }^{34}$ and that is not allowed under a structural understanding of international legal order which PRIL must maintain, in conformity with PIL principles. ${ }^{45}$ It is interesting that while scholars look to PIL to increase corporate social responsibility, the association with PIL, rather than private law makes PRIL an unlikely forum to support that goal and might even render the efforts of PIL scholars futile.

\section{From PIL General Principles to PRIL General Principles}

In addition to reforming the tort choice of law rules the Supreme Court also used Tolofson to outline what it viewed as the general goals of choice of law. The Court not only linked choice of law rules to general principles of PIL, but also committed the goals of choice of law to what it views as the requirements of the international legal order. Allegedly, the application of the law of the place of tort responds to "sound practical considerations" in that "the rule has the advantage of certainty, ease of application and predictability," ${ }^{46}$ as well as limiting the possibility of forum shopping. ${ }^{47}$

Just as the court was ambiguous about who might be the addressee of the principle of territoriality, it is equally ambiguous about who might be the addressee of the policies informing the area of choice of law, such as certainty, ease of application and predictability. The court decries forum shopping and pleads for security of transactions. ${ }^{48}$ Because of the ambiguity in the theoretical foundation of choice of law, the court does not engage in an analysis of when forum shopping might be in order; either because the same law can still be legitimately applied to the defendant regardless of where the case is heard or because this law serves another public interest which could trump private interests, or both.

Rather, once the court established a relationship with PIL, it seemed to it "axiomatic" that the exercise of legislative jurisdiction in the international arena must be "exclusive". 49 "The government of

\footnotetext{
43 Paul, supra note 3 at 167.

44 Tolofson, supra note 6 at para 57.

45 See Mills, supra note 41 who creates an analogy between PRIL and constitutional law.

46 Tolofson, supra note 6 at para 44.

$47 \quad$ Ibid at para 52.

$48 \quad$ Ibid at para 44.

49 Ibid at para 43.
} 
that place [of the tort] is the only one with power to deal with these activities" and "the same expectation is shared by other states". ${ }^{50}$ Public policy considerations are allegedly too parochial. The forum must respect the fact that foreign laws "are usually enacted on the basis of what are often perceived by those who make them as reasonable, though they may turn out to be unwise. The residents of the jurisdiction must put up with them until they are modified" ${ }^{51}$ And even though "it may be unfortunate for a plaintiff that he or she was the victim of a tort in one jurisdiction rather than another and so be unable to claim as much compensation as if it had occurred in another jurisdiction [...] such differences are concomitant to the territoriality principles" 52 which was a priori chosen as the governing one. It is truly this circular analysis which leads the court to conclude that "while no doubt, as was observed in Morguard, the underlying principles of private international law are order and fairness, order comes first." 53

By first deducing choice of law rules from PIL general principles and then extending general PIL principles of universal consensus and peaceful co-existence to PRIL, the court injected an additional limitation in PRIL by placing order above all other goals in PRIL.

\section{Parties' reasonable expectations - A Fictional Concept?}

Finally, the reasoning in Tolofson obscures what would otherwise be a fundamental question in determining when the application of one state's law or another is legitimate relative to the defendant. For example, Brilmayer has suggested that the application of the defendant's law of the domicile should be legitimate because of the political link that the defendant maintains with this state. ${ }^{54}$ It is in the same vein that Seck and Macklin refer to the "corporate citizen" and suggest that a corporation conducting business abroad can still expect that the state of its main place of business might regulate its extraterritorial activity. ${ }^{55}$ Instead, because of the association it makes between Private and Public International law, the Supreme Court is most concerned that in essence by applying the law of the forum for conduct occurring abroad, the forum's court purports to "define the nature and consequences of an act done in another country" ${ }^{56}$ and this is seen as an affront to territorial sovereignty, a principle which was a priori chosen to govern the area of tort choice of law.

Overall, the concept of parties' reasonable expectations as a methodological tool in determining the applicable law and as a justification for the application of such law is viewed as a "somewhat fictional concept" ${ }^{57}$ This completes the line of arguments used by the Court to describe PRIL as a structural set of norms which are meant simply to distribute authority among states in a uniform way, in conformity with general principles of PIL.

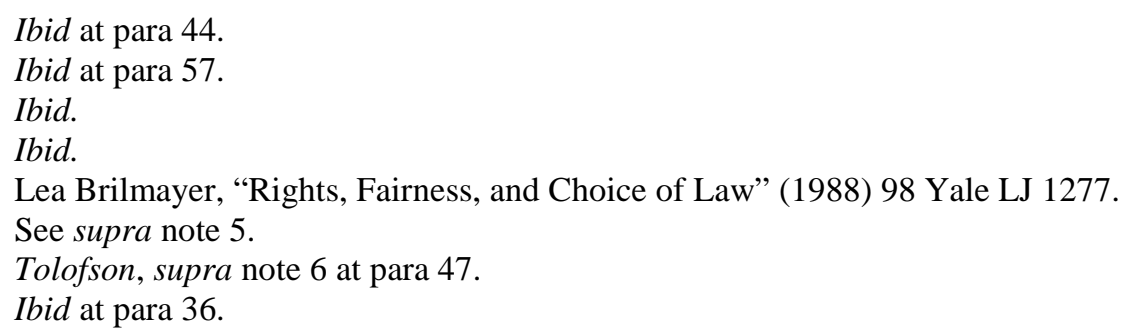




\section{THE 19TH CENTURY PIL-PRIL ASSOCIATION}

Although the Supreme Court presented its approach in Tolofson as adapting PRIL to modern realities and constructing a modern theory of the relationship between PRIL and PIL, this association has deep roots in the history of PRIL. ${ }^{58}$ However, contemporary scholarly accounts of the history of the PRILPIL association remain quite vague. ${ }^{59}$ This section examines some of the actual discourse of several key PRIL scholars of the end of the $19^{\text {th }}$ century who have argued for a strong relationship between PILPRIL ("the law of nations theory" ${ }^{60}$ ). A comparison between the line of arguments in Tolofson and that of the law of nations scholars underscores the state-centric premises of the reasoning and the implications it has for the area of choice of law, especially in tort matters.

The association between PIL and PRIL was a widespread theme within the universalist doctrine from the mid- $19^{\text {th }}$ century until the first few decades of the $20^{\text {th }}$ century. ${ }^{61}$ However, there was a wide range of arguments regarding the scope and the limits of this association. ${ }^{62}$ Interestingly, some of the strongest universalist theories based on the PIL-PRIL relationship were written towards the end of the $19^{\text {th }}$ century when it was felt that it must be established once and for all that "the conflict is between two sovereigns and it involves one of their essential attributes, namely their legislative functions; such conflict of sovereigns automatically falls under the scope of PIL". ${ }^{63}$ It was argued that PRIL is not really concerned with private interests, but with questions of state sovereignty because "even if a PRIL matter might be occasioned by a private interest, this interest has been considered so important that it has been elevated to the level of a public interest". ${ }^{64}$

The analogy was a reflection of the socio-political context of the time, as well as of the way in which legal theory described the scope of international law. ${ }^{65}$ In a particularly revealing statement, the French scholar Antoine Pillet (1857-1926) explained that "either PRIL is not really law and has no mandatory character for states or it does have a mandatory character but then it becomes a part of PIL which settles

58 For an overview of this association see Mills, supra note 41; Nussbaum, supra note 15. For an overview of the contemporary debate regarding this association see the panel discussion , Peter D Trooboff et al, "The Increasing Focus of Public International Law of Private Law Issues” in Proceedings of the Annual Meeting (1992) 86 American Society of International Law 456; Th M de Boer, "Living Apart Together: the Relationship Between Public and Private International Law” (2010) 57 Nethl Int'l L Rev 183; Mills, supra note 41; S Leibe \& M Ruffert eds, Völkerrecht und IPR (Jena Germany: Jenaer Wissenschaftliche Verlagsgesellschaft, 2006). See also Ralf Michaels, "Private and Public International Law, German Views on Global Issues” (2008) 4 J Priv Intl L 121.

See Nussbaum, supra note 15; Pavel Kalenský, Trends of Private International Law (Prague: Czechoslovak Academy of Sciences, 1971).

62 See Antoine Pillet, Principes de Droit International Privé (Paris: Pedone, 1903) at 56-60 on the variety of ways in which the PRIL-PIL relationship was conceptualized in PRIL scholarship, during the $19^{\text {th }}$ century [Pillet, Principes].

63 l'enseignement superior de Grenoble (Grenoble: F Allier Père \& Fils, 1892) at 333 [Pillet, Rapport] [translated by the author].

${ }_{64}$ Ibid at 345 [translated by the author].

65 Kalenský, supra note 61. 
relationships between states and establishes the limits of their respective legislative competence with respect to rights and private interests". 66

Another French scholar, Henri Batiffol (1905-1989) tellingly described PIL's impact on PRIL in the following words:

In a world divided into independent states, all relationships, even between individuals, which extend beyond the borders of a particular state, involve the relationship between states: the international society is one made up of states; if an individual enters into a relationship, even a purely commercial one, with another individual pertaining to another state, this relationship is considered to belong to public international law because no relationship can be established between individuals belonging to different states but within the framework of inter-state relationships, in other words within the framework of public international law. ${ }^{67}$

The association between PIL and PRIL was not necessarily the result of a pure doctrinal conviction of the nature of PRIL. Rather, it was often offered as an "inevitable" solution for achieving a uniform set of rules which prevent clashes of legislative authority. ${ }^{68}$ In the Supreme Court's words, it is viewed as the inevitable means of achieving "a rational and workable system of rules" of division of authority. ${ }^{69}$ The $19^{\text {th }}$ century law of nations scholarship not only narrowed the universalist argument, but as will be discussed below, it isolated PRIL from both public and private law.

These were self-imposed limitations because as $19^{\text {th }}$ century opponents of the theory have argued, there is nothing per se in the name "international" that makes it necessary to conceptualize the relationship between PRIL and PIL in a formalistic way. ${ }^{70}$ Instead, it was argued that "PRIL scholars who did not have a clear idea of PRIL's goal, but were perfectly aware of the obstacles created by territorial sovereignty focused on the obstacle, and ignored the more distant goal". ${ }^{71}$

Alternatively, another universalist group of $19^{\text {th }}$ century scholars identified the goal of PRIL as "analyzing the social purpose of each legal relationship and determining the rules of law which would be most suitable for the attainment of its social purpose in the international society". ${ }^{2}$ However, this perspective remained unnoticed during the development of the universalist doctrine in PRIL and it continues to be excluded from contemporary historical accounts of this doctrine.

66 Pillet, Principes, supra note 62 at 56 [translated by the author].

67 See Henri Batiffol, "Principes de Droit International Privé”, Collected Courses of the Hague Academy of International Law, vol 97 (Hague: Hague Academy of International Law, 1959) at 437-438 [translated by the author].

68 F Laurent thought that integrating PRIL within PIL is necessary to achieve a uniform science of PRIL. F Laurent, Droit civil international, vol1 (Bruxelles: Bruyland Christophe \& Co., 1880) at 9.

69 Tolofson, supra note 6 at 37.

70 Josephus Jitta, La Methode de Droit International Privé (The Hague: Belinfante Frères, 1890) at 34-35 [Jitta, “La methode"] [translated by the author].

71 Ibid at 41 [translated by the author].

72 Ibid at 217 [translated by the author]. 


\section{A. From General Principles of PIL to Choice of Law Rules}

The first consequence of the association between PRIL-PIL was the assumption that choice of law rules must reflect and comply with general principles of PIL. ${ }^{73}$ Law of nations scholars firmly believed that PRIL rules must reflect general postulates of PIL which designate the optimal distribution of legislative authority among states. ${ }^{74}$

Most law of nations scholars acknowledged that PIL in its traditional formulation dealt with interstate relationships. Therefore, there could not be a direct relationship between the inter-human relationships regulated by PRIL and PIL. ${ }^{75}$ Instead, to conceptualize such relationship one had to determine a relationship between private rights and the state and then a relationship among states with respect to private rights. ${ }^{76}$ Such determinations culminated in the conclusion that "private rights can be created with a well-founded claim to international recognition only by that state which possesses the general governmental control over the subject with respect to which the subjective private law confers authority". 77

When devising PRIL rules, "law of nations" scholars would often reference an express or tacit consent among states regarding the limits of "their public powers in an international context". ${ }^{78}$ Personal and territorial sovereignty, or the scope of a state's "public functions", were interpreted in such way as to lead to what were claimed to be "axiomatic" rules of PRIL. ${ }^{79}$ The fact that PIL did not appear to directly reference PRIL matters was of no concern, since to extract PRIL norms from PIL principles was viewed as "the responsibility of the legal academic community". ${ }^{80}$ Scholars presented a number of alleged examples of "a general consensus" on the scope of territorial and personal sovereignty for many categories of cases while at the same time acknowledging that "once one understands the dependence of private international law on public international law, the attainable can be easily distinguished from the unattainable. If public international law does not provide for clear principles of division of legal authority among states, no uniform principles of PRIL can be found. If uniformity in PRIL is missing it is entirely attributable to public international law". ${ }^{81}$

\section{B. From General Principles of PIL to General Principles of PRIL}

In addition to choice of law rules, law of nations scholars also derived the guiding postulates of PRIL from general principles of PIL. Probably the one leaving the strongest mark on PRIL theory and methodology was the belief that PRIL rules must be uniform, predictable, and have a high degree of generality. Because law of nations scholars conceived of PRIL matters as conflicts of sovereignties it

\footnotetext{
73 Because of the assumption that PRIL rules can be deduced from principles of PIL this methodology has been labeled as the "deductive methodology" in PRIL by Ernest Lorenzen. See Ernest Lorenzen, Selected Articles on the Conflict of Laws (New Haven: Yale University Press, 1947) at 18.

74 See Kalenský, supra note 61.

75 Ernst Zitelmann, Internationales Privatrecht, vol 1 (Leipzig: Dunkler \& Humblot, 1897) at 41.

76 Ibid.

77 Ibid at 68 [translated by the author].

78 Antoine Pillet, “Le droit international public, ses elements constitutifs, son domaine, son objet” (1894) 1 RGDIP at 4, 4142.

79 Ibid; Zitelmann, supra note 75.

80 Zitelmann, supra note 75 at 20 [translated by the author].

81 Ibid at 78 [translated by the author].
} 
seemed axiomatic to them that "devising uniform rules of conduct among states is the unifying element of public and private international law". ${ }^{82}$ Law of nations scholars offered a wide range of justifications for the need for uniformity; from concerns for breach of state sovereignty to a general concern for uncertainty in international transactions. ${ }^{83}$ However, the main consideration, derived from PIL, seems to be that if PRIL matters are viewed as conflicts of legislative jurisdiction, a state's legislative jurisdiction is always exclusive which means that only one answer to a conflict of legislative jurisdiction is possible and acceptable under PIL. ${ }^{84}$ The unifying principle of PIL and PRIL is that "each state is obliged not to attribute to itself a legal authority which is not recognized by public international law". ${ }^{85}$

\section{PRIL Matters are Structural Problems}

By describing PRIL matters as conflicts of sovereignties and opting for order and predictability as the most important principles in PRIL "law of nations" scholars concluded that PRIL matters are structural problems. Understanding the conflict of laws term literally, they denied virtually any association between PRIL and private law. ${ }^{86}$ The fear that a rapprochement of PRIL towards private law would lead to particularism was as strong then as it is now. ${ }^{87}$ By opting for broad choice of law rules, which are merely meant to achieve a distribution of state authority, law of nations scholarship remained oblivious to the ultimate result of the application of a particular law. In its most extreme variation, law of nations scholarship claimed that private interests are not directly involved, because the limit of the authority of law is nothing more than a limit of the "public power of a state" in relationship to another state. ${ }^{88}$

Similarly, even those who described conflict of laws matters as conflicts of "public powers" or "public interests" believed the state interests which are at stake and collide with each other, both in public and private international law should be based on a general classification. ${ }^{89}$ It cannot be left to the discretion of the judge to determine and weigh the interests on a case-by-case basis, because this is allegedly too uncertain and can lead to arbitrary decisions and abuses. ${ }^{90}$ Furthermore, such classification is possible because only a handful of pre-determined interests, which are essential for the performance of state functions, can be reasonably claimed by states under PIL principles. ${ }^{91}$ Much like the Supreme Court, law of nations scholars believed interest balancing simply obscures the structural nature of PRIL matters and leads to fundamental misunderstandings of this area of law. ${ }^{92}$

82 Pillet, "Rapport", supra note 63 at 327 [translated by the author].

83 For a critique of the various rather vague justifications of the law of nations scholars see Franz Kahn, "Die Lehre vom ordre public" in Abhandlungen zum internationalen Privatrecht (Munich, Leipzig: Duncker \& Humblot, 1928) at 194

86 Carl Ludwig von Bar, "Neue Prinzipien und Methoden des internationalen Privatrechts” (1900), 15 Archiv für öffentliches Recht 1

87 For a $19^{\text {th }}$ century perspective see Pillet, “Principes”, supra note 62 at 57; For a contemporary perspective see Mills, supra note 41.

88 Pillet, "Rapport”, supra note 63 at 335.

89 Ibid.

90 Ibid.

91 Antoine Pillet, Recherches sur les droit fundamentaux des états dans l'ordre des rapports internationaux et sur la solution des conflits qu'ils font naitre (Paris: A. Pedone, 1899) at 63

92 Von Bar, supra note 86 at 16 


\section{Individual Reasonable Expectations - a Fictional Concept?}

Describing PRIL matters as structural problems led law of nations scholars to conclude that individuals' reasonable expectations are a problematic consideration in PRIL for two reasons. Firstly, because of their concern for order and predictability, they might have viewed parties' reasonable expectations as a fluid concept which injects too much flexibility into the adjudicatory process. Secondly, because in their view, what was truly at stake in PRIL, was state sovereignty; "it is entirely wrong to assume that the individual has a right to the application of a certain law, because the limits of the authority of law are not fixed by consideration to private interests, but result from the limits of the public powers which enacted them”. ${ }^{93}$ Their almost complete state-centric orientation is most tellingly captured in Antoine Pillet's remark that since PRIL norms achieve a distribution of authority between states "the litigating parties disappear for a while". ${ }^{94}$

It was this radical state-centric orientation which led several law of nations scholars to argue that when a court is asked to recognize the application of foreign law and rights granted by such law, the request does not come from "a person, a simple individual”, but rather "a foreign sovereign" and failure to apply this law would result in "an infringement of the public law of the foreign sovereign", rather than an injustice to one or both litigating parties. ${ }^{95}$ Because states were viewed as the subjects of PRIL, it became difficult to find any place in PRIL's methodology for consideration of the parties' reasonable expectations. This explains why in the area of tort law for example, theoretical perspectives arguing that in some cases the application of the home state's law may both correspond to the expectations of the affected local community of the host state, as well as to those of corporations operating abroad, remain excluded. Instead, the state-centric perspective of the law of nations scholars which has been revived in Tolofson appears to justify the concern that if PRIL is understood only as an area for settling conflicts of authority between states "PRIL becomes a species of supreme law, a law of laws, placed to such extent above the individuals, that it can disregard them". 96

\section{CONCLUSIONS}

In an attempt to adapt PRIL to "modern realities” the Supreme Court of Canada linked both choice of law rules, as well as the general policy goals of the area of PRIL to general principles of PIL. However, the Supreme Court thereby revived a particular understanding of this relationship, one which predominated in continental Europe, especially in the second half of the $19^{\text {th }}$ century. By arguing that PRIL imposes a uniform distribution of authority among states in conformity with broad principles of PIL, the Supreme Court injected an overly state centric understanding of PRIL which disconnects this area of law from both private and public law.

In the context of transnational torts this association between PRIL and PIL leads to an almost exclusive focus on questions of state sovereignty, territoriality and comity. In this way, the application of the law of the place of tort is believed to be axiomatic. This precludes an analysis of when and why

93 Pillet, "Rapport", supra note 63 at 335 [translated by the author].

94 Ibid [translated by the author].

95 Mailhé de Chassat, Traité de statuts (lois personelles, lois réelles), d'après le droit ancienes et le droit modern, ou du Droit International Privé (Paris: A Durand, 1845) at 214 [translated by the author].

96 Jitta, supra note 30 at 5 [translated by the author]. 
the application of the defendant's home state law might still be legitimate relative to the defendant and in conformity with both parties' reasonable expectations. It also eliminates a rich consideration of international public policy and the impact of the application of one or the other law on various socioeconomic sectors.

Yet the need for this association between PRIL-PIL is by no means self-evident. Rather, it appears to be a relic of a particular kind of universalist argument which is most clearly observed in $19^{\text {th }}$ century continental European PRIL scholarship. This argument is making a come-back in contemporary scholarship and jurisprudence based on the misconception that this is the only way in which to construct an internationalist theory of PRIL. Yet, in the history of PRIL scholarship there were other, marginalized theories which pled for more nuanced internationalist perspectives which incorporated both public and private law concerns. When attempting to "update" PRIL to the requirements of international social life, a richer understanding of the universalist argument would be more suitable, especially in the area of transnational torts. ${ }^{97}$

97 In my SJD dissertation I uncover this alternative, lesser known conceptualization of universalism in PRIL scholarship in the $19^{\text {th }}$ century (in progress, at the University of Toronto, Faculty of Law). 